\title{
Internal and External Factors Effects towards Return on Assets in Indonesian Foreign Exchange Sharia Bank
}

\author{
Rizal $^{1 \%}$, Farid Ahmad Marlion ${ }^{2}$, Himyar Pasrizal ${ }^{3}$, Rini Anita ${ }^{4}$ \\ FEBI IAIN Batusangkar, Sumatera Barat, Indonesia ${ }^{2,3,4}$
}

Submitted: 15 September, 2020; Accepted: 24 July, 2021; Published: 29 July, 2021

\begin{abstract}
This study aims to analyze the influence of internal factors such as financing and third-party funds, as well as external factors including inflation, BI, and exchange rate against Return On Asset (ROA) at Indonesian Foreign Exchange Sharia Bank. Furthermore, the library research was used and quantitatively described. Also, using the total sampling technique, the research team obtained six sample banks, namely Bank Mega Syariah, Muamalat Indonesia, Panin Dubai Syariah, BNI Syariah, BRI Syariah, and Bank Syariah Mandiri. The data include Balance Sheet and Profit, Loss Financial Statements, as well as the published reports on inflation, BI, or exchange rates obtained in a quarterly period from 2015 to 2019 . According to the F-test, there was a significant influence between the independent variables (Financing, Third Party Funds, Inflation, BI, and Exchange Rates) on the dependent (ROA). Meanwhile, the t-test showed there was no significant effect of partial financing, Third Party Funds, BI rate $\left(\mathrm{X}_{4}\right)$, and Kurs $\left(\mathrm{X}_{5}\right)$ on the ROA. Therefore, this study showed there was an increase in ROA because the society involves in financing due to high inflation.
\end{abstract}

Keywords: internal and external factors, return on assets (ROA), Indonesian foreign exchange sharia bank 


\section{INTRODUCTION}

Profitability is a company's ability to generate profits (Marginingsih, 2018) by using total existing assets (Swandayani \& Kusumaningtias, 2012). There are eight criteria to measure profitability level, namely Gross Profit Ratio, EBITDA (Earnings Before Interest, Taxes Depreciation, dan Amortization), Operating Profit Margin, Net Profit Margin (NPM), Cash Flow Margin, Return on Assets (ROA), Return on Equity (ROE), and Return on Invested Capital (ROIC) as stated in the circular letter of Bank Indonesia No.6/23/DPNP on May 31, 2004.

The higher the ROA(Gumanti, 2011), the more the profit (Syah, 2018), and the better the its position in terms of asset used (Lalujan, Pelleng, \& Tumbel, 2016). Based on Bank Indonesia Circular SE No.13/24/DPNP in October 25th 2011, the ideal minimum ROA requirement is $1.5 \%$. In other words, when the profit made is below the stipulated value, the bank is not optimal in managing its assets.

The research team used ROA as profitability indicator. This is because Bank Indonesia prioritizes profitability as measured by assets whose funds mostly come from public deposits. It is also the most objective measurement method based on available accounting data. Therefore, the amount of ROA can reflect series results of company policies, especially banking. Also, it is a measure of the financial performance in obtaining profit before tax, as generated from the total assets(Swandayani \& Kusumaningtias, 2012).

Determinant factors of profitability are classified as internal and external (Ernayani, Moorcy, \& Sukimin, 2017). The internal factors include fundraising, as well as the managements of capital, liquidity, and cost. Meanwhile, the external are beyond management control, such as competition, regulation, concentration, market share, ownership, scarcity of capital, money supply, inflation, interest rates, foreign exchange rates, economies of scale, and bank size(Syah, 2018).

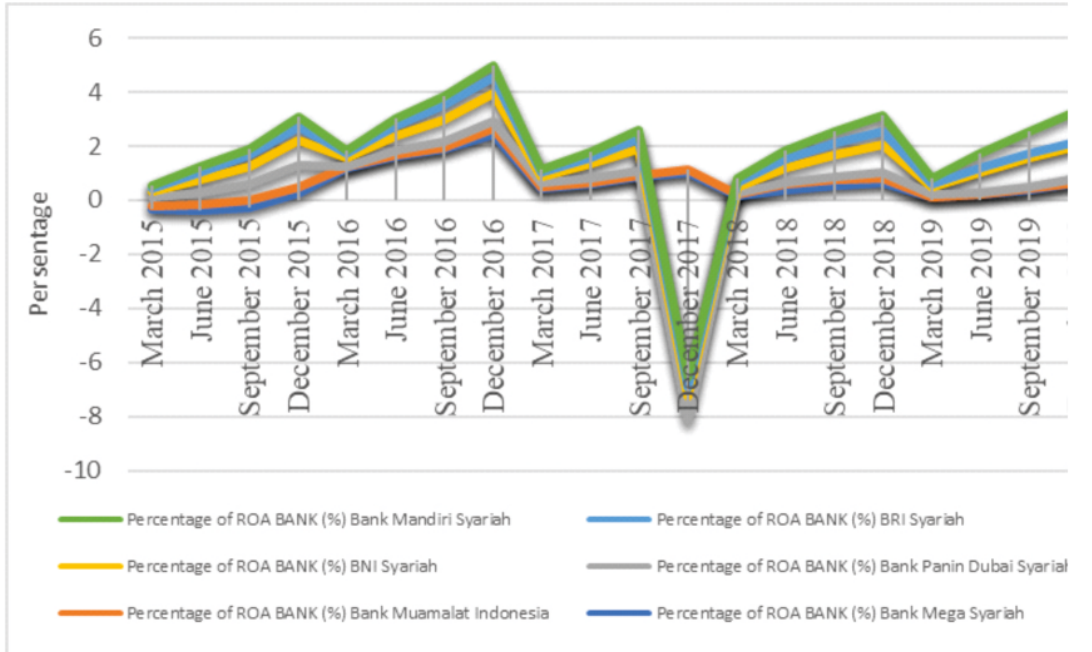

Graph 1. ROA (Return on Asset) Data of Indonesian National

Sharia Commercial Banks for Foreign Exchange 2015-2019 
Based on the statistical data of BUSN Foreign Exchange Indonesia, the profitability performance projected by ROA in the quarterly period from 2015 to 2019 fluctuated, while the average percentage of ROA was $0.30 \%$, which is clearly far from the provisions set by Indonesian Bank. Furthermore, the highest percentage was 2.45\% at Sharia Mega Bank in December 2016, while the lowest was 9.27\% at Sharia Panin Dubai Bank in December 2017. Out of the 120 samples, only three were above the provisions of SE No.13 / 24 / DPNP regarding the acquisition of ROA minimum percentage with $2.5 \%$ total sample. Meanwhile 97.5\% of ROA percentage at BUSN Foreign Exchange Indonesia was below minimum provisions issued by Bank Indonesia (OJK, 2020). Conversely, Third Party Funds and Financing showed a positive trend with a stable average amount. This is in line with Bank Syariah Mandiri on December 2019 which increased to Rp.73,560,845,000,000 from the previous Rp.47,868,721,000,000 in March 2015. Also, third party funds increased significantly from Rp.59,198,066,000,000 on March 2015 to Rp.99,809,730,000,000 on December 2019.

Indonesia's average inflation reflected a positive trend of 3.88\% from March 2015 to December 2019, which was below 10\%, hence classified as mild. Inflation is classified into four levels, namely mild, moderate, severe, and hyperinflation. The mild occurs when increase in price is below $10 \%$, moderate between $10 \%-30 \%$, hyperinflation between $30 \%-100 \%$ in a year. Meanwhile, hyperinflation or uncontrolled inflation occurs when price increases are above $100 \%$ a year (Hambarsari \& Inggit, 2016). According to the average percentage of the BI Rate, there was a decrease in fluctuation from March 2015 to March 2018. However, it increased in June 2018 to June 2019, and decreased in September and December 2019. The average exchange rate against the US Dollar increased from quarter March 2015 to December 2019. In addition, it was noted that the Rupiah exchange rate against the Dollar was Rp. 14,017.00(BI, 2020).

In carrying out its operational activities, banks as an intermediary institution cannot be separated from the influence of internal and external factors. The internal factors affecting profitability include the Amount of Financing and Third-Party Funds (TPF). Rahman and Rochmanika(2012) stated that the higher the level of Mudharabah and Musyarakah financing, the greater the profitability level of Sharia banks. Also, the amount of ROA is influenced by net income obtained from profit sharing in financing(Azmi, 2016).

Beside internal factors, banks cannot be separated from the influence of economic development conditions on macroeconomic theory. In this case, arising from external factors (government and central bank policies) the main objective is to maintain monetary stability, 
such as the balance sheet of payments, national income (gross domestic and gross national products), as well as the rates of economic growth, inflation, unemployment, foreign exchange, money supply and interest(Swandayani \& Kusumaningtias, 2012).

Third Party Fund (TPF) is an internal factor affecting profitability, which has a positive and significant effect on bank performance (ROA). This means the more TPF the bank can acquire, the higher its performance (ROA) (Sudiyatno \& Suroso, 2010). This has a positive significance as the most influential variable to profitability (Anggreni \& Suardhika, 2014). In contrast to previous studies, Muliawati and Khoiruddin (2015) stated that the variable has no significant effect on the profitability of Sharia Commercial Banks. This is in line with Sihombing and Yahya (2016) that there was no significant effect of TPF on the profitability of Islamic banking in Indonesia. Furthermore, Third Party Funds have no effect on the profitability of Islamic Commercial Banks in Indonesia during 2012-2015 (Fitriana \& Musdholifah, 2017). Dasari and Wirman (2020) also showed there was no effect on profitability.

Beside internal factors, in the implementation of its operational activities, banks cannot be separated from the influence of economic development conditions on macroeconomic theory. In this case, they arise from external factors (government and central bank policies) whose main objective is to maintain monetary stability, such as balance sheets, payment, national income (gross domestic and gross national products), as well as the rates of economic growth, inflation, unemployment, foreign exchange, money supply and interest (Swandayani \& Kusumaningtias, 2012). As an intermediary institution, banks are vulnerable to inflation risk. When a country has high inflation, it will result to an increase in consumption, which will consequently affect the pattern of saving and financing in the society. This change will directly impact the operational activities of banks, where the amount of funds collected from the public will decrease, and have an impact on performance in earning income and generating profits(Sukirno, 2006).

According to Dwijayanthy and Naomi (2009), there was a significant relationship between the inflation and exchange rates on profitability, while the BI rate was insignificant. Furthermore, Hidayati(2014) showed that the variable rate of inflation and exchange rate had a significant influence on the profitability of Islamic banks. Syah (2018) proved there was a significant effect of BI on ROA. Moreover, Swandayani and Kusumaningtias(2012) stated that the variables of inflation, interest rates, foreign exchange rates, and the money supply gave a significant effect on the ROA of sharia banking in Indonesia. However, Ady (2020) showed the exchange rate had a negative or no significant effect on the profitability in Indonesian banks. 
Macroeconomic and internal factors are variables that affect banking, among which inflation is insignificant (Istan \& Fahlevi, 2020). According to Sukirno (2013). This variable gave a negative effect on profitability. The higher the inflation rate, the lower the ROA ratio. Basically, an increase in this variable indicates economic growth, but it is detrimental for longer period. Therefore, the high rate causes the prices of domestic goods to be relatively more expensive than imported ones. Also, the real value of savings or third-party funds can decline with increase in financing since people withdraw funds from banks due to expensive local goods. This is in line with the increase in exchange rates as a result of increment in domestic goods prices, and cheap imports.

Based on the above background, a research gap was discovered, where theoretically, an increment in financing and TPF increase ROA. The facts showed the ROA of Indonesian Foreign Exchange BUSN gave a negative trend although the amount of financing and TPF tends to increase. On the other hand, inflation showed a positive trend, although, from the BI rate, there were fluctuations that tend to fall in the last period with an increase in the exchange rate. Therefore, it becomes a research question, whether the amount of financing, TPF, inflation, BI Rate, and exchange rates affect ROA on Foreign Exchange BUSN 2012-2019. This study was limited by internal and external factors, where the former consist of the amounts of financing and third-party funds, while the latter consists of inflation, BI rate, and exchange rate.

Based on these limitations, the problems can be formulated as follows, First, the influence of financing amount on Return on Assets. Second, the influence of third-party funds on Return on Assets. Third, the effect of the inflation rate on Return on Assets. Fourth, the effect of BI rate on Return on Assets. Fifth, the effect of the exchange rate on Return on Assets. Sixth, the influence of financing, third party funds, inflation, BI rate, and exchange rates simultaneously on Return on Assets.

\section{METHOD}

The data were in the form of quarterly Financial Statistic Reports obtained from March 2015 to December 2019. Also, data on the average inflation, BI, and exchange rates were obtained accordingly. These were categorized as secondary which is panel data (pooling) in the form of time-series and cross-section. Furthermore, the data were obtained from six BUSN Foreign Exchange Indonesia, namely Bank Mega Syariah, Bank Muamalat Indonesia, Bank Panin Dubai Syariah, BNI Syariah, BRI Syariah, and Bank Syariah Mandiri, as well as the website of the Financial Services Authority, the Central Bureau of Statistics, or the official 
websites. These banks were chosen because they are allowed to carry out banking activities related to foreign currencies, transfers abroad, export-import transactions, and other foreign exchange services. Furthermore, the two variables used are independent, such as financing, third party funds, inflation, BI rate, or exchange rate, and dependent, which includes Return on Assets (ROA). Eviews 10 was utilized since the data were longitudinal or panel. This analysis technique includes several stages, as follows.

\section{Selection of a Regression Model}

The panel data regression model equation is written as:

$$
\begin{aligned}
& \text { Yit }=\alpha+\beta 1 \text { X1it }+\beta 2 \text { X2it }+\beta 3 \text { X3it }+\beta 4 \text { X } 4 \text { it }+\beta 5 \text { X } 5 \text { it }+ \text { eit } \\
& \text { Information: } \\
& \mathrm{Y}=\mathrm{ROA} \\
& \mathrm{X} 1=\text { Financing } \\
& \mathrm{X} 2=\text { Third Party Funds } \\
& \mathrm{X} 3=\text { Inflation } \\
& \mathrm{X} 2=\mathrm{BI} \text { rate } \\
& \mathrm{X} 1=\text { Exchange rate } \\
& \mathrm{i}=\operatorname{unit}(\text { Bank) } \\
& \mathrm{t}=\text { period of time (year/ quarter) } \\
& \alpha=\text { constant } \\
& \mathrm{e}=\text { output variable }
\end{aligned}
$$

To estimate the model coefficients on the data, an estimation model was carried out with three possibilities, namely 1) Common Effect Model (CEM), it ignores the dimensions of time and space owned, in other words, it is a technique of panel data analysis by combining cross section and times series data as a single unit without distinguishing time or bank. 2) Fixed Effect Model (FEM), a panel data estimation technique which uses dummy variables or differential intercept dummies to cover the intercept differences. 3) Random Effect Model (REM), estimates panel data where disturbance variables may be interrelated over time and between individuals. This model is often called the Error Component Model (ECM) (Ghozali \& Ratmono, 2018).

Furthermore, the panel test stage according to Iqbal (2015) suggested that after carrying out the test phase by choosing the panel data regression method, subsequently, the estimation model should be determined as follows 1) F Test (Chow Test), when the prob value at $\mathrm{F}$ is smaller than the significance, the fixed is chosen rather than the common effect, and vice 
versa when the prob is greater. 2) Hausman Test, when prob. Chi squares is smaller than significance, the fixed effect is chosen over random, and vice versa when prob. Chi squares is greater. 3) Lagrange Multiplier (LM) Test, when the prob value is smaller than the significance, random effect is chosen rather than common, and vice versa when the prob is greater.

Subsequently, the classic assumption test was carried out to analyze the relationship between the dependent and independent variables as follows 1) Normality test, determined whether there was a normal distribution of confounding or residual variables in the retrogression model. 2) Multicollinearity test, aimed to test whether the regression model found a high or perfect correlation between independent variables. 3) The autocorrelation test, aimed to determine the presence or absence of autocorrelation in a model, according to the Durbin-Watson statistical value by comparing with the Durbin-Watson table. 4) Heteroscedasticity test, aimed to determine whether the residuals of the model formed had constant variance or not. Furthermore, the selection of analysis methods or hypothesis testing was carried out as follows, 1) The coefficient of determination (R2) was used to measure the extent which the independent variables can explain the dependent variable. 2) t test, was carried out to check the regression coefficient individually. 3) The f test was conducted to determine the effect of the independent variables (amount of financing, amount of third party funds, inflation, BI Rate, and exchange rate) on the dependent variable (Return on Asset) simultaneously (Ghozali \& Ratmono, 2018).

\section{RESULT ANDDISCUSSION \\ Classic Assumptions}

Based on the determination of the estimation method used, such as the F-Test (Chow Test), the selected model was fixed effect, where the probability F value was $(0.0000)<0.05$. The same model was also chosen in the Hausman Test, with a probability F value of $(0.0258)$ $<0.05$. Since the fixed effect model was used in this study, the Lagrange Multiplier test was not required. Therefore, the classical assumption test was carried out, with the results as follows.

\section{Normality Test}

Test Normality used fallow jarque method with the results outlined in the following figure 


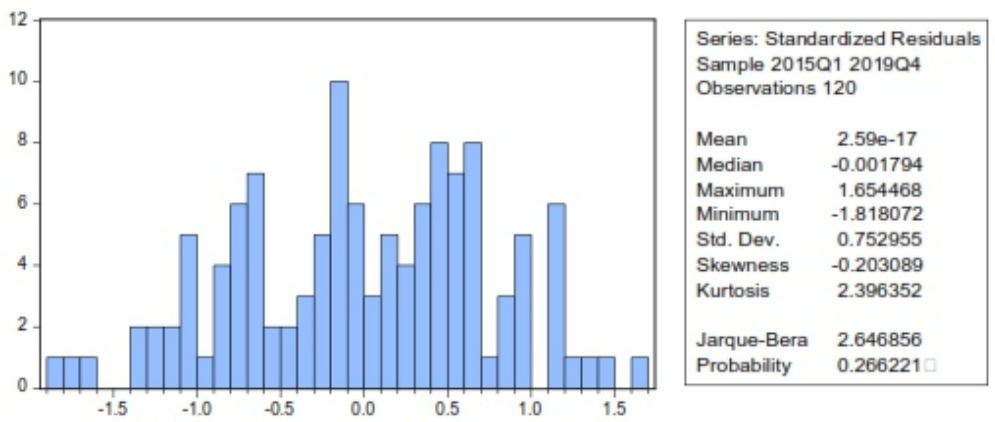

Graph 2. Normality Test Results

Based on Graph 2, the results were obtained in the form of a jarque-bera probability test value of 0.266221 . The JB test value was greater than the significance level $(0.266221>$ $0.05)$, hence, the H0 was accepted and the residual had a normal distribution.

\section{Multicollinearity Test}

The multicollinearity test results are as follows.

Table 1. Multicollinearity Test Results

\begin{tabular}{lrrrrr}
\hline \hline & \multicolumn{2}{c}{ Financing Third_Party_Funds } & Inflation & BI_Rate & Exchange_Rate \\
\hline \hline Financing & 1.000000 & 0.844854 & -0.088726 & -0.070605 & 0.065916 \\
Third_Party_Fun.0.844854 & 1.000000 & -0.100232 & -0.086432 & 0.071062 \\
Inflation & -0.088726 & -0.100232 & 1.000000 & 0.520295 & -0.356573 \\
BI_Rate & -0.070605 & -0.086432 & 0.520295 & 1.000000 & 0.119324 \\
Exchange_Rate & 0.065916 & 0.071062 & -0.356573 & 0.119324 & 1.000000 \\
\hline \hline
\end{tabular}

According to Table 1, the independent variables were lower than 0.90 . This is consistent with Ghozali and Ratmono (2018) which stated that when the results of the multicollinearity test do not exceed 0.90 it indicates that there is no high correlation value between the independent variables, therefore, there is no multicollinearity between the variables.

\section{Autocorrelation Test}

Autocorrelation Test Results are as follows.

Table 2. Autocorrelation Test Results

\begin{tabular}{lrlr}
\hline \hline R-squared & 0.402024 & Mean dependent var & $-9.81 \mathrm{E}-16$ \\
Adjusted R-squared & 0.358926 & S.D. dependent var & 1.053253 \\
S.E. of regression & 0.843309 & Akaike info criterion & 2.569071 \\
Sum squared resid & 78.93984 & Schwarz criterion & 2.778133 \\
Log likelihood & -145.1443 & Hannan-Quinn criter. & 2.653972 \\
F-statistic & 9.328255 & Durbin-Watson stat & 1.759781 \\
Prob(F-statistic) & 0.000000 & & \\
\hline \hline
\end{tabular}


Based on the output, the Durbin-Watson Stats result was (1.759781). Observing the Durbin Watson table with the provisions $(\alpha=0.05)$, the following sample size $(n)=120$, and the variables in this study were 6 , with 1 dependent and 5 independent variables at $(\mathrm{dl}=1.61642)$ and $(\mathrm{du}=1.78964)$, therefore, $1.61642<\mathrm{DW}<1.78964$. In other words, these variables do not contain autocorrelation.

\section{Heteroscedasticity Test}

To determine the heteroscedasticity test, the White and Glejser method was used, with the results as follows.

Table 3. White's Heteroscedasticity Test Results

\begin{tabular}{llll}
\hline \hline \multicolumn{1}{l}{ Heteroskedasticity Test: White } & & \\
\hline \hline F-statistic & 0.752588 & Prob. F(5,114) & 0.5859 \\
Obs*R-squared & 3.834423 & Prob. Chi-Square(5) & 0.5735 \\
Scaled explained SS & 3.455558 & Prob. Chi-Square(5) & 0.6301 \\
\hline \hline
\end{tabular}

According to the results, the smallest chi-square was (0.5753), which means that it was above the value of $\alpha(0.05)$. Therefore, $\mathrm{H} 0$ was accepted and there was no heteroscedasticity problem. The following is the heteroscedasticity test using the Glejser method, with this output;

Table 4. Glejser Test Heteroscedasticity Results

\begin{tabular}{llll}
\hline \hline \multicolumn{4}{l}{ Heteroskedasticity Test: Glejser } \\
\hline \hline F-statistic & 1.102012 & Prob. F(5,114) & 0.3633 \\
Obs*R-squared & 5.532647 & Prob. Chi-Square(5) & 0.3544 \\
Scaled explained SS & 5.280798 & Prob. Chi-Square(5) & 0.3826 \\
\hline \hline
\end{tabular}

Based on Table 4., the smallest chi-square was (0.3544), which indicated that it was above the value of $\alpha=0.05$. Therefore, $\mathrm{H} 0$ was accepted with no heteroscedasticity problem.

Based on the test methods above, it can be concluded that the Chi-square value was small with the value $\alpha=0.05$, hence, there was no heteroscedasticity problem.

\section{Hypothesis Test}

\section{Determination Coefficient Test (R2)}

Due to the estimation, the fixed effect model was selected, while the test results for the coefficient of determination (R2) are as follows 
Table 5. Fixed Effect Model Results

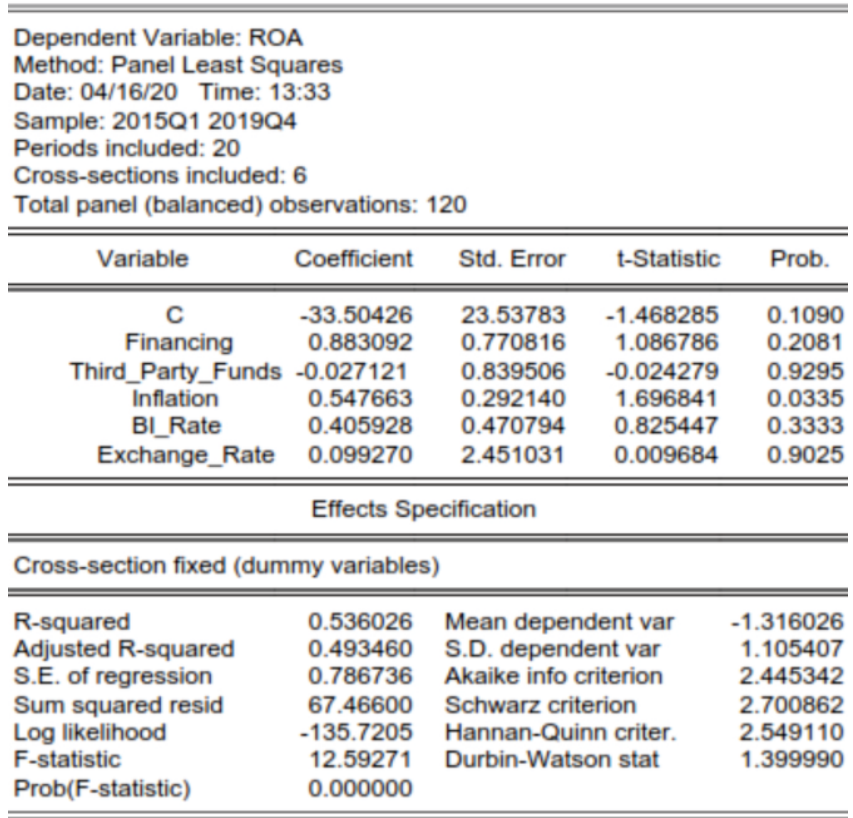

According to Table 5, the coefficient of determination R2 (R-Squared) was 0.536026 or $53.60 \%$. Therefore, the dependent variable (ROA) can be explained by the independent, which include both internal factors of Financing (X1) and Third-Party Funds (X2), as well as the external factors, such as Inflation (X3), BI-Rate (X4) and Exchange Rates (X5) amounting to $53.60 \%$, with the remaining $46.40 \%$ explained by other variables outside this research model.

\section{T-test}

The partial test results can be determined by observing the prob and $t$ statistical values of the fixed-effect model (FEM) as the selected estimation model with the following results

Table 6. T-Test Results

\begin{tabular}{lcccc}
\hline \multicolumn{1}{c}{ Variable } & t-Statistic & Prob. & $\alpha$ & Conclusion \\
Financing & 1.086786 & 0.2081 & 0.05 & Not significant \\
Third-Party Funds & 0.024279 & 0.9295 & 0.05 & Not significant \\
Inflation & 1.696841 & 0.0335 & 0.05 & Significant \\
BI Rate & 0.825447 & 0.3333 & 0.05 & Not significant \\
Exchange rate & 0.009684 & 0.9025 & 0.05 & Not significant \\
\hline
\end{tabular}

The hypothesis testing of each variable is shown below. First hypothesis H0: There was no significant effect of financing on ROA. Ha: Financing had a significant influence. Based on Table 6 , the t-test results in the first hypothesis stated that the $t$ value of the financing variable was 1.086786 with a significance value of 0.2081 , hence, it was insignificant because it was 
greater than the $\alpha$ value (0.05). According to the first hypothesis, $\mathrm{H} 0$ was accepted and $\mathrm{H} 1$ was rejected. Therefore, it can be concluded that financing did not have a significant effect on ROA at the Indonesian Foreign Exchange National Sharia Commercial Bank

Second hypothesis H0: There was no significant effect of Third Party Funds on Return on Asset. Ha: Third-Party Funds gave a significant influence. The t-test results on the second hypothesis testing of Third Party Funds stated that the t value was -0.024279 with a significance of 0.9295, hence, it was insignificant since the value was greater than $\alpha(0.05)$. Therefore, $\mathrm{H} 0$ was accepted and $\mathrm{H} 1$ rejected. It can be concluded that Third Party Funds do not have a significant effect on ROA.

Third hypothesis H0: Inflation gave no significant effect on ROA. Ha: There was a significant effect of inflation. In testing the third hypothesis with this variable, the $t$ value was 1.696841 with a significance value of 0.0335 , which was lower than $\alpha(0.05)$. Therefore, $\mathrm{H} 0$ was rejected and $\mathrm{H} 1$ accepted. It can be concluded that there was no significant effect of inflation on ROA..

Fourth hypothesis H0: BI rate was insignificant on Return on Asset. Ha: BI rate had a significant influence. This showed that the t count of BI Rate was 0.825447 with a significance value of 0.3333 , which is greater than the $\alpha(0.05)$. Therefore, H0 was accepted and H1 rejected. In conclusion, the BI rate was insignificant on ROA.

Fifth hypothesis H0: Exchange rate was insignificant on ROA. Ha: There was a significant effect on the Exchange rate. According to this variable, the t value was 0.009684 with a significance value of 0.9025 , which is greater than $\alpha(0.05)$. Therefore, $\mathrm{H} 0$ was accepted and $\mathrm{H} 1$ rejected. In conclusion, the exchange rate was insignificant on ROA.

\section{FTest}

In estimating the data, a significance level of $5 \%$ or 0.05 was used. Based on the data processing conducted, the following hypothesis testing results were discovered

Tabel 7. Test Results f

\begin{tabular}{cccc}
\hline F-statistic & Prob (F -statistic) & $\alpha$ & Conclusion \\
\hline 12.59271 & 0.000000 & 0.05 & Significant
\end{tabular}

According to Table 7, the F-statistic value was 12.59271 with a prob (F-statistic) of 0.000000 , which showed that prob. F-statistic $<0.05$. Therefore, H0 was rejected, while H1 was accepted. It can be concluded that the amount of financing and third-party funds, as well as the inflation, BI rate, and the exchange rate simultaneously gave a significant effect on Return on Assets. 


\section{CONCLUSION}

The results of panel data regression analysis showed that the internal factor variables included Financing, and Third Party Funds. External factors, such as Inflation, BI rate, and exchange rates simultaneously had a significant effect on the ROA of the Indonesian Foreign Exchange National Sharia Commercial Bank at 53.60\%, while the remaining $46.40 \%$ was explained by other unexamined variables. According to the t-test, partially the Financing variable (X1), Third Party Funds (X2), BI rate (X4), and Exchange Rate (X5) were insignificant on ROA. Meanwhile, there was a significant influence on inflation.

Return on Assets is one of the criteria for measuring profitability level by comparing profit before tax with total assets, and it is affected by internal and external factors. Based on the results from external factors, the inflation variable gave a significant influence on ROA. This indicated that an increase in this variable can have a positive effect on increasing the Return on Assets. It can be related to inflation when prices on a certain level also rise. Therefore, to survive, people undergo financing in sharia banks. The higher the financing, the greater the ROA will be when the level of non-performance financing decreases. The increase in inflation will also have an impact on the BI rate because one of the government's ways of reducing inflation is to increase customer's interest in saving funds at financial institutions. However, in this study, there was no inflation of BI rate on Indonesian Foreign Exchange Sharia Bank since the interest principle is not used in its operations, but rather determines the profit-sharing on savings and investments.

\section{BIBLIOGRAPHY}

Ady, R. A. (2020). Pengaruh Makroekonomi terhadap Profitabilitas Perbankan di Indonesia. Research Fair Unisri 2019, 4(1), 115-126. http://dx.doi.org/10.33061/rsfu.v4i1.3393.

Anggreni, M. R., \& Suardhika, I. M. S. (2014). Pengaruh Dana Pihak Ketiga, Kecukupan Modal, Risiko Kredit dan Suku Bunga Kredit pada Profitabilitas. E-Jurnal Akuntansi, $9(1), 27-37$.

Azmi, F. (2016). Volume Effect Analysis Financing to Profitability with BOPO as Variable Moderation the Islamic Banks in Indonesia. Jurnal Ebbank, 7(2), 93-104.

Dasari, S. A., \& Wirman. (2020). The Effect of Third Party Funds and Non Performing Financing Towards Return on Assets of Sharia Commercial Banks in Indonesia (Period 2014-2019). Nisbah, 6(2), 124-130. http://dx.doi.org/10.30997/jn.v6i2.3164.

Dwijayanthy, F., \& Naomi, P. (2009). Analisis Pengaruh Inflasi, BI Rate, dan Nilai Tukar Mata Uang terhadap Profitabilitas Bank Periode 2003-2007. Karisma, 3(2), 87-98. 
Ernayani, R., Moorcy, N. H., \& Sukimin. (2017). Faktor-Faktor yang Mempengaruhi Return on Assets (Studi Pada Bank Umum Syariah di Indonesia Periode 2011-2016). Prosiding Seminar Nasional dan Call for Paper Ekonomi dan Bisnis (SNAPER-EBIS), 284-293.

Fitriana, S., \& Musdholifah. (2017). Pengaruh Faktor Internal dan BI Rate Terhadap Profitabilitas Bank Umum Syariah Periode 2012-2015. Jurnal Ilmu Manajemen, 5(3), $1-15$.

Ghozali, I., \& Ratmono, D. (2018). Analisis Multivariat dan Ekonometrika (Teori, Konsep, dan Aplikasi dengan Eviesw 10) (2nd ed.). Semarang: Badan Penerbit Universitas Diponegoro.

Gumanti, T. A. (2011). Manajemen Investasi: Konsep, Teori dan Aplikasi. Jakarta: Mitra Wacana Media.

Hambarsari, D. P., \& Inggit, K. (2016). Analisis Pengaruh Pertumbuhan Ekonomi, Pertumbuhan Penduduk dan Inflasi Terhadap Tingkat Kemiskinan di Jawa Timur Tahun 2004-2014. JEB1 7: Jurnal Ekonomi dan Bisnis, 1(2), 257-282. https://doi.org/ 10.1234/jeb17.v1i02.915.

Hidayati, A. N. (2014). Pengaruh Inflasi, BI Rate dan Kurs Terhadap Profitabilitas Bank Syariah di Indonesia. An-Nisbah, 1(1). 72-97. https://doi.org/10.21274/an.2014.1.1. 72-97.

Iqbal, M. (2015). Pengolahan Data dengan Regresi Linier Berganda dengan Eviews 8. Perbanas Intitute.

Istan, M., \& Fahlevi, M. (2020). The Effect of External and Internal Factors on Financial Performance of Islamic Banking. Jurnal Ekonomi \& Studi Pembangunan, 21(1), 137-145. https://doi.org/10.18196/jesp.21.1.5036.

Lalujan, D. N., Pelleng, F. A. O., \& Tumbel, T. M. (2016). Analysis of Bank Indonesia Rate of Return on Assets at the PT. Bank Mandiri tbk Manado. Jurnal Administrasi Bisnis (JAB), 4(3), 1-12. DOI: https://doi.org/10.35797/jab.4.3.2016.12894.\%25p.

Marginingsih, R. (2018). Faktor-Faktor yang Mempengaruhi Profitabilitas Bank Umum Syariah di Indonesia. Ecodemica: Jurnal Ekonomi, Manajemen, dan Bisnis, 2(1), 7485.

Muliawati, S., \& Khoiruddin, M. (2015). Faktor-faktor Penentu Profitabilitas Bank Syariah di Indonesia. Management Analysis Journal, 4(1), 39-49. https://doi.org/10.15294/maj. v4i1.7211. 
Rahman, A. F., \& Rochmanika, R. (2012). Pengaruh Pembiayaan Jual Beli, Pembiayaan Bagi Hasil, dan Rasio Non Performing Financing terhadap Profitabilitas Bank Umum Syariah di Indonesia. Iqtishoduna, 8(1), 1-16. https://doi.org/10.18860/iq.v0i0.1768.

Sihombing, N. H., \& Yahya, M. R. (2016). Pengaruh Kebijakan Spin-Off, Beban Operasional Pendapatan Operasional (BOPO), Dana Pihak Ketiga (DPK), dan Non Performing Financing (NPF) Terhadap Profitabilitas Perbankan Syariah di Indonesia. Jurnal Ilmiah Mahasiswa Ekonomi Akuntansi, 1(2). 127-137.

Sudiyatno, B., \& Suroso, J. (2010). Analisis Pengaruh Dana Pihak Ketiga, BOPO, CAR dan LDR Terhadap Kinerja Keuangan Pada Sektor Perbankan yang Go Public di Bursa Efek Indonesia (BEI) (Periode 2005-2008). Dinamika Keuangan dan Perbankan, 2(2). 125-137.

Sukirno, S. (2006). Ekonomi Pembangunan: Proses, Masalah, dan Dasar Kebijakan. Jakarta: Kencana Prenada Media Group.

Sukirno, S. (2013). Mikroekonomi Teori Pengantar. Jakarta: PT. RajaGrafindo Persada

Swandayani, D. M., \& Kusumaningtias, R. (2012). Pengaruh Inflasi, Suku Bunga, Nilai Tukar Valas dan Jumlah Uang Beredar terhadap Profitabilitas Pada Perbankan Syariah di Indonesia Periode 2005-2009. Akrual: Jurnal Akuntansi, 3(2), 147-166. https://doi. org/10.26740/jaj.v3n2.p147-166.

Syah, T. A. (2018). Pengaruh Inflasi, BI Rate, NPF, dan BOPO terhadap Profitabilitas Bank Umum Syariah di Indonesia. El-Jizya : Jurnal Ekonomi Islam, 6(1), 133-153. https:// doi.org/10.24090/ej.v6i1.2051

\section{Website:}

BI. (2020). Bank Indonesia. https://www.bi.go.id/id/statistik/informasi-kurs/transaksibi/default.aspx.

OJK. (2020). Otoritas Jasa Keuangan. https://www.ojk.go.id/id/kanal/perbankan/data-danstatistik/laporan-keuangan-perbankan/Default.aspx 